University of Nebraska - Lincoln

DigitalCommons@University of Nebraska - Lincoln

Faculty Papers and Publications in Animal

Science

Animal Science Department

May 1983

\title{
TESTICULAR GROWTH IN BOARS OF DIFFERENT GENETIC LINES AND ITS RELATIONSHIP TO REPRODUCTIVE PERFORMANCE
}

\author{
Allan Schinckel \\ University of Nebraska-Lincoln \\ R. K. Johnson \\ University of Nebraska-Lincoln, rjohnson5@unl.edu
}

R. A. Pumfrey

University of Nebraska-Lincoln

Dwane R. Zimmerman

University of Nebraska-Lincoln

Follow this and additional works at: https://digitalcommons.unl.edu/animalscifacpub

Part of the Animal Sciences Commons

Schinckel, Allan; Johnson, R. K.; Pumfrey, R. A.; and Zimmerman, Dwane R., "TESTICULAR GROWTH IN BOARS OF DIFFERENT GENETIC LINES AND ITS RELATIONSHIP TO REPRODUCTIVE PERFORMANCE " (1983). Faculty Papers and Publications in Animal Science. 33.

https://digitalcommons.unl.edu/animalscifacpub/33

This Article is brought to you for free and open access by the Animal Science Department at DigitalCommons@University of Nebraska - Lincoln. It has been accepted for inclusion in Faculty Papers and Publications in Animal Science by an authorized administrator of DigitalCommons@University of Nebraska - Lincoln. 


\title{
TESTICULAR GROWTH IN BOARS OF DIFFERENT GENETIC LINES AND ITS RELATIONSHIP TO REPRODUCTIVE PERFORMANCE ${ }^{1}$
}

\author{
Allan Schinckel ${ }^{2}$, R. K. Johnson ${ }^{3}$, R. A. Pumfrey ${ }^{4}$ and Dwane R. Zimmerman ${ }^{3}$ \\ University of Nebraska, Lincoln 68583
}

\section{Summary}

Testicular growth of 377 boars was compared by obtaining in situ measurements of testes width and length and excised tissue weights. Two experiments involved a line selected nine generations for ovulation rate (OR) and a control line (CL), and two experiments contained boars of the OR line and two other lines; WL, a Large White-Landrace cross, and a line founded by crossing lines OR and CL and selected six generations for increased average daily gain and decreased backfat (LG line). In situ testes measurements were similar for the $O R$ and $C L$ lines and were curvilinearly related to age. The LG line had smaller in situ measurements than the OR line $(P<.05)$ when both unadjusted means and means adjusted for body weight were compared. The OR line had $10.5 \%$ heavier testes than the CL line at $90.8 \mathrm{~kg}$ and a 9 to $15 \%$ advantage at $120,141,162$ and $183 \mathrm{~d}$ of age. The OR line had more rapid testicular development from 120 to $183 \mathrm{~d}$ of age $(P<.05)$ than the CL line. The LG line had significantly lower excised testes weights ( 17 to $50 \%$ less), a lower percentage of tubules that showed active spermatogenesis and lower mean diameter of the seminiferous tubules $(P<.05)$ than the $O R$ line. The relative differences between lines $O R$, $C L$ and LG suggest that selection for lean growth rate has resulted in less rapid testicular development and increased age at puberty. The correlations of testes weights and in situ testes measurements taken at the time of castration were between .76 and .93 . The correlations of testes width and testes length with epididymides

\footnotetext{
${ }^{1}$ Published as Paper No. 6926 Journal Series, Nebraska Agr. Exp. Sta.

'Present address: Anim. Sci. Dept., Purdue Univ., West Lafayette, IN 47907.

${ }^{3}$ Anim. Sci. Dept., Univ. of Nebraska.

${ }^{4}$ Present address: Fairbault, MN 55021.
}

weights were slightly lower, and correlations of body weight and testes weight ranged from .51 to .70 . Mean diameter of the seminiferous tubules and percentage of tubules with active spermatogenesis were correlated with measurements of testes size $(r=.50$ to .61$)$ and body weight at the time of castration ( $r=.29$ to .36$)$. Correlations of excised testes weights with number born in the boar's contemporary litter and ovulation rate of full sibs were uniformily positive. The correlations of measurements of testes size and backfat ( $r=-.09$ to .20 ) suggest that the phenotypic relationship between testes growth and body composition is small. However, the response found in the LG line suggests a negative genetic relationship between lean growth rate and testicular growth rate.

(Key Words: Boars, Testicular Growth, Ovulation Rate, Lean Growth, Reproduction.)

\section{Introduction}

Improved reproductive efficiency will increase the overall efficiency of swine production. Response to selection could be improved if some characteristic of the boar could be used as a predictor of the reproductive efficiency of genetically related females. The same gonadotropic hormones stimulate the gonads of both sexes, and a positive relationship between testis size and ovulation rate has been found in mice (Land, 1973; Islam et al., 1976; Joakimsen and Baker, 1977) and sheep (Carr and Land, 1973).

Testicular growth may be an indicator of the reproductive performance of boars. Lines or crosses that have larger testes at a constant age generally have greater sperm numbers and superior mating efficiency (Hauser et al., 1952; Wilson et al., 1977; Neely et al., 1979).

Selection for lean growth rate may delay sexual maturation. Andresen (1976) found significantly higher levels of $5 \alpha$-androstenone and testosterone in the systemic plasma of 
boars selected for fatness and a low rate of gain than in boars selected for low backfat thickness and a high rate of gain. Gray et al. (1971) found that the testosterone level in the spermatic vein blood of boars with the highest backfat was significantly higher than the testosterone level of boars with the lowest backfat. Allrich et al. (1981) found that selection for efficiency of lean growth in rats decreased testes weight at $85 \mathrm{~d}$ of age. Also, increased age and weight at vaginal opening were found in lines selected for both rate and efficiency of lean growth.

This paper presents the results of four experiments that were conducted to evaluate 1) differences in rates of tesicular growth among lines that differed in ovulation and growth rate and 2) relationship of testes growth with body weight, age and reproductive characteristics of female relatives.

\section{Materials and Methods}

Data were collected during four experiments from 377 boars. Experiments 1 and 2 involved the Gene Pool line selected for increased ovulation rate $(O R)$ and the control line $(C L$;
Zimmerman and Cunningham, 1975). No significant correlated responses in growth traits (Newton et al., 1977) or carcass traits (England et al., 1977; Cunningham et al., 1979) have been found in the OR line.

The first experiment involved the measurement of 103 ( $48 \mathrm{CL}$ and $55 \mathrm{OR}$ ) boars of the first generation of relaxed selection following nine generations of selection for ovulation rate. Boars were randomly assigned to be castrated at $225 \mathrm{~d}$ of age or $90.8 \mathrm{~kg}$ (table 1). They were fed ad libitum from about $60 \mathrm{~d}$ of age to about $90.8 \mathrm{~kg}$; interval feeding $(4 \mathrm{~h} / \mathrm{d})$ was used thereafter.

In situ measurements of testes width (TWH) and testis length (TL) were started at $84 \mathrm{~d}$ of age when the boars weighed approximately 31 $\mathrm{kg}$. Measurements were made with the use of calipers and were taken at approximately 3 -wk intervals up until the time of castration. Boars were snared and measured while standing squarely on a level floor. Three to six measurements were made on boars that were castrated at $90.8 \mathrm{~kg}$. Seven measurements were made on boars castrated at $225 \mathrm{~d}$ of age. The TWH was the width of both testes, and TL was the length

TABLE 1. NUMBER OF BOARS IN EACH EXPERIMENT

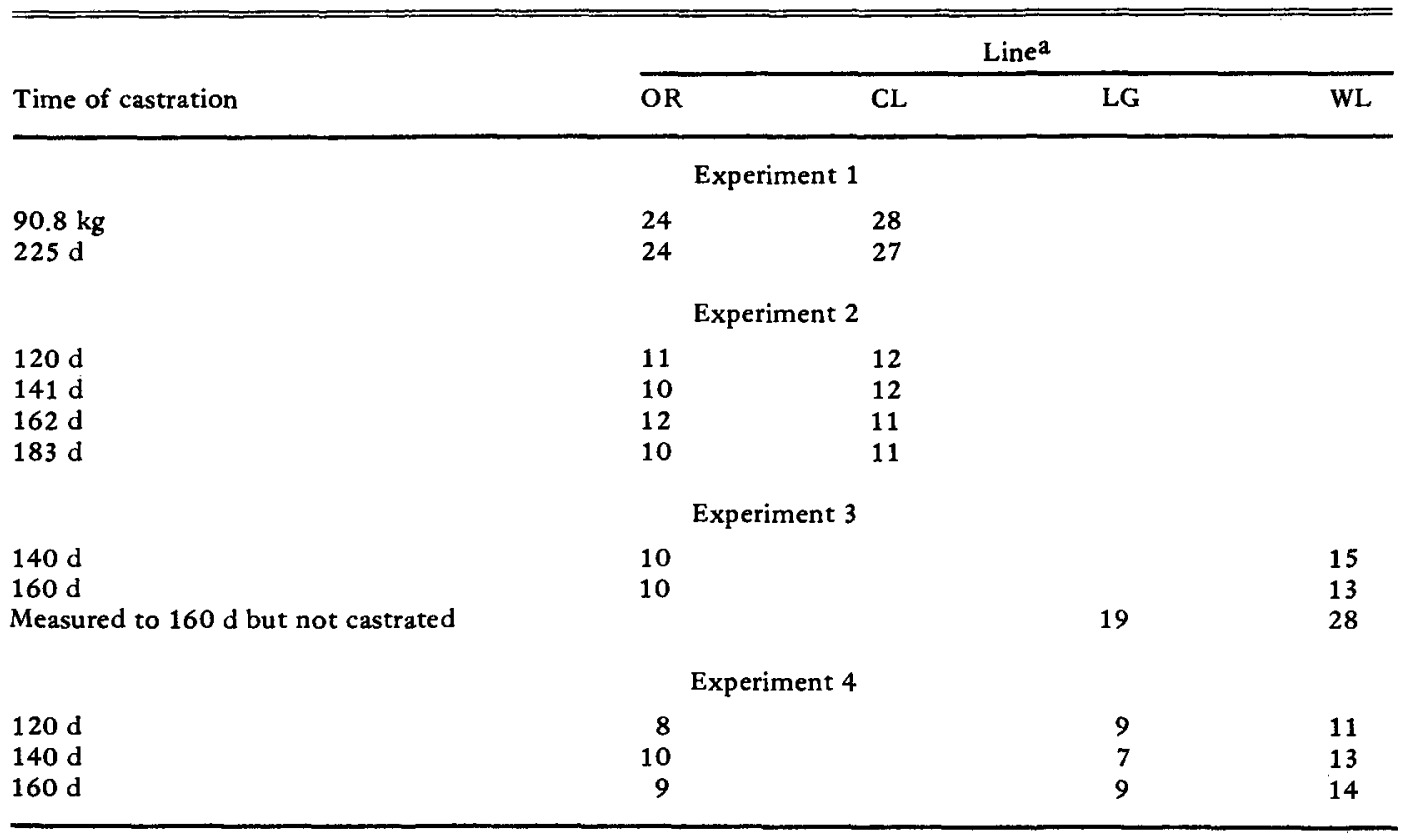

${ }^{a} \mathrm{OR}=$ ovulation rate select, $\mathrm{CL}=$ ovulation rate control, $\mathrm{LG}=$ index select for average daily gain and backfat, $\mathrm{WL}=$ cross among Large White and Landrace. 
of the testis from the top of the epididymis to the bottom of the testis.

Boars were anesthetized with sodium thiamylal and eastrated. The tissues were wrapped in plastic bags and placed on ice until weights were determined ( 4 to $6 \mathrm{~h}$ ). Total testis (testis + epididymis, TTW), testis (without epididymis, TW) and epididymis weights (EW) were taken. The weights of both sides were added for analyses.

In Exp. 2, 89 ( $46 \mathrm{CL}$ and $43 \mathrm{OR}$ ) boars of the second generation of relaxed selection were randomly assigned to be castrated at either $120,141,162$ or $183 \mathrm{~d}$ of age (table 1). Boars were fed ad libitum. Measurements of testes width, testis length and body weight were taken at each age until castration.

The third experiment included 95 boars of lines LG, OR and WL. The OR boars were a sample from the second generation of relaxed selection. The LG line was formed from a cross of third generation OR and CL line pigs (Cleveland et al., 1982) and was mass selected for six generations on the index: $I=100+286.6$ (average daily gain, $\mathrm{kg}$ )-100 (backfat, $\mathrm{cm}$ ). Total response after five generations was $.08 \mathrm{~kg}$ average daily gain, $-.18 \mathrm{~cm}$ backfat and 29 index units (Cleveland et al., 1982). The WL boars were the $F_{1}$ offspring of reciprocally. crossed Landrace and Large White and were included to improve the precision of within line estimates of correlation coefficients.

One-half of the WL boars and all of the LG boars were needed for breeding, and only intact testes measurements were taken. The remaining WL and OR boars were castrated at 140 or 160 $\mathrm{d}$ of age. The boars were fed ad libitum, and body weight and in situ measurements of testicular growth were taken at 120, 140 and $160 \mathrm{~d}$ of age.

The fourth experiment included 90 boars of lines LG, OR and WL. Boars were randomly assigned to be castrated at either 120,140 or $160 \mathrm{~d}$ of age. The LG and OR boars were of the second and third generations of relaxed selection, respectively, and the WL boars were of the $\mathrm{F}_{2}$ generation. Boars were fed ad libitum, and in situ measurements of testicular growth were taken at 100, 120, 140 and $160 \mathrm{~d}$ of age.

Histological measurements were made in Exp. 4. Immediately after the testes were weighed, two wedges of tissue were taken from the left testis of each boar. The tissue samples were fixed for $24 \mathrm{~h}$ in Bouins fluid and then transfered to $70 \%$ ethanol. Fixed tissues were embedded in paraffin wax, and 5 to $7-\mu \mathrm{m}$ sections were stained with hematoxylin-eosin. The mean seminiferous tubule diameter was calculated from the measurement of 40 round tubules (20 tubules/original tissue sample). The percentage of tubules having a lumen and showing active spermatogenesis were estimated from the evaluation of 100 tubules ( 50 tubules/ tissue sample).

Statistical analysis of data was made by general linear model procedures (SAS, 1979). The models used to analyze the data are presented in table 2 . In situ measurements and body weights, which were taken at several ages on each boar were fitted to model 1. In addition, the data were analyzed according to model 1 with age considered a continuous variable. The effects of age, age ${ }^{2}$, age $x$ line and age $^{2} \times$ line were examined. The boar within

TABLE 2. MODELS USED FOR ANALYSES

\begin{tabular}{|c|c|c|c|}
\hline Model no. & Experiment & Modela $^{\mathrm{a}}$ & Traits $^{b}$ \\
\hline 1 & $1,2,3,4$ & $\mathrm{Y}_{\mathrm{ijk}}=\mu+\mathbf{L}_{\mathbf{i}}+\mathbf{B}_{\mathbf{j}} / \mathrm{L}_{\mathbf{i}}+\mathrm{A}_{\mathbf{k}}+\mathrm{A}^{*} \mathbf{L}_{\mathrm{ik}}+\mathrm{e}_{\mathrm{ijk}}$ & BW, TL, TWH \\
\hline 2 & 3,4 & $Y_{i j k}=\mu+L_{i}+B_{j} / L_{i}+A_{k}+A * L_{i k}+b B W_{i j k}+e_{i j k}$ & TWH, TL \\
\hline 3 & $1,2,3,4$ & $\mathrm{Y}_{\mathrm{ijk}}=\mu+\mathrm{L}_{\mathrm{i}}+\mathrm{A}_{\mathrm{k}}+\mathrm{A}^{*} \mathrm{~L}_{\mathrm{ik}}+\mathrm{e}_{\mathrm{ijk}}$ & TTW, TW, EW \\
\hline 4 & $2,3,4$ & $Y_{i j k}=\mu+L_{i}+A_{k}+L^{*} A_{i k}+b B W_{i j k}+e_{i j k}$ & TTW, TW, EW \\
\hline
\end{tabular}

\footnotetext{
${ }^{a}$ Definition of terms: $\mu=$ overall mean; $L_{i}=$ fixed effect of $i$ th line; $B_{j} / L_{i}=$ random effect of $j^{\text {th }}$ boar of the $i^{\text {th }}$ line; $A_{k}=$ fixed effect of the $k^{\text {th }}$ constant age; $A^{*} L_{i k}=$ interaction of the $i^{\text {th }}$ line and $k^{\text {th }}$ age; $b=p$ artial regression of $\mathrm{Y}$ on the independent variable, pooled across lines and ages; $B W_{i j k}=$ body weight of the $\mathrm{j}^{\text {th }}$ boar of the $i^{\text {th }}$ line at the $k^{\text {th }}$ age; $Y=$ observation; $e_{i j}$, $e_{i j k}=$ residual.

${ }^{b} \mathrm{BW}=$ body weight, $\mathrm{TL}=$ in situ testes length, $\mathrm{TWH}=$ in situ testes width, $\mathrm{TW}=$ testes weight, EW = epididymides weight and $T T W=$ testes + epididymides weight.
} 
line mean square was used for testing line effects, and the residual mean square was used for testing age and interaction effects.

The data from Exp. 3 and 4 were fitted to model 2 to estimate the partial regression of testes measurements on body weight, pooled across lines and ages. Preliminary analyses failed to reveal a significant interaction between either age or line and the regression of testes measurements on body weight.

Excised testes weights from all experiments, and the histological traits from Exp. 4, were fitted to model 3 . Model 4 was used to estimate the regression coefficient for excised testes weights on body weight for data from Exp. 2, 3 and 4 . The regressions of testes weights on body weight were pooled across lines and ages because the interactions of the regression on body weight were not significant.

The usefulness of in situ measurements to predict actual testes and epididymides weight was evaluated by estimating the pooled within line correlations of testes width and length at the time of castration with the excised tissue weights. In Exp. 2, 3 and 4, the correlations were not significantly different at the various ages and were pooled across lines and ages.

Experiment 4 data were used to calculate within line correlations of histological measurements with measurements of testes size and body weight.

Correlation coefficients of female reproductive traits with testicular measurements and histological traits of the boars were calculated to evaluate the usefulness of testicular characteristics as predictors of female reproduction. Female reproductive traits included ovulation rate (ORFS) and age at puberty (APFS) of full sibs. Also included were available data for dam's age at puberty (DAMPUB), dam's ovulation rate (DAMOR), the size of litter in which a boar was born (NBORN) and weaned (NWEAN) and the number born in the dam's previous litter (NBORNI). Correlations were calculated within line and castration age and pooled. For APFS and ORFS, the record for each boar was

TABLE 3. LEAST-SQUARES MEANS FOR OVULATION RATE SELECT (OR) AND CONTROL LINES (CL) FOR IN SITU TESTES MEASUREMENTS

\begin{tabular}{|c|c|c|c|c|c|c|}
\hline \multirow[b]{2}{*}{ Line } & \multirow{2}{*}{$\begin{array}{l}\text { Measurement } \\
\text { age, d }\end{array}$} & \multirow[b]{2}{*}{ No. } & \multicolumn{2}{|c|}{ Testes width $(\mathrm{cm})$} & \multicolumn{2}{|c|}{ Testis length $(\mathrm{cm})$} \\
\hline & & & $\overline{\mathbf{X}}$ & SE & $\overline{\mathbf{x}}$ & $\mathrm{SE}$ \\
\hline \multicolumn{7}{|c|}{ Experiment 1} \\
\hline OR & 84 & 48 & 5.81 & .11 & 6.32 & .12 \\
\hline & 112 & 48 & 8.19 & .11 & 8.70 & .12 \\
\hline & 132 & 48 & 10.08 & .11 & 10.68 & .12 \\
\hline & 153 & 43 & 11.43 & .12 & 12.31 & .14 \\
\hline & 173 & 29 & 12.59 & .15 & 13.22 & .17 \\
\hline & 198 & 25 & 13.29 & .16 & 14.08 & .19 \\
\hline & 225 & 24 & 13.86 & .17 & 15.08 & .20 \\
\hline \multirow[t]{7}{*}{ CL } & 84 & 55 & 5.77 & .11 & 6.24 & .13 \\
\hline & 112 & 55 & 8.28 & .11 & 8.82 & .13 \\
\hline & 132 & 54 & 10.00 & .11 & 10.61 & .13 \\
\hline & 153 & 47 & 11.24 & .12 & 12.41 & .14 \\
\hline & 173 & 42 & 12.74 & .15 & 13.63 & .18 \\
\hline & 198 & 28 & 13.21 & .17 & 14.25 & .20 \\
\hline & 225 & 27 & 13.68 & .17 & 14.96 & .20 \\
\hline \multicolumn{7}{|c|}{ Experiment 2} \\
\hline OR & 120 & 43 & 8.30 & .10 & 9.05 & .11 \\
\hline & 141 & 32 & 9.72 & .13 & 10.60 & .15 \\
\hline & 162 & 22 & 10.80 & .16 & 11.54 & .18 \\
\hline & 183 & 10 & 11.65 & .24 & 12.66 & .27 \\
\hline \multirow[t]{4}{*}{ CL } & 120 & 46 & 8.22 & .10 & 8.90 & .11 \\
\hline & 141 & 34 & 9.37 & .13 & 10.55 & .14 \\
\hline & 162 & 22 & 10.32 & .17 & 11.57 & .19 \\
\hline & 183 & 11 & 11.13 & .23 & 12.29 & .26 \\
\hline
\end{tabular}


TABLE 4. OVULATION RATE SELECT (OR) AND CONTROL (CL) LINE LEAST-SQUARES MEANS FOR EXCISED TESTES AND EPIDIDYMIDES WEIGHTS ${ }^{a}$

\begin{tabular}{|c|c|c|c|c|c|c|c|c|}
\hline \multirow{2}{*}{$\begin{array}{l}\text { Time of } \\
\text { castration }\end{array}$} & \multicolumn{4}{|c|}{ Testes weight $(\mathrm{g})$} & \multicolumn{4}{|c|}{ Epididymides weight (g) } \\
\hline & OR & $\mathrm{SE}$ & CL & SE & OR & SE & CL & SE \\
\hline \multicolumn{9}{|c|}{ Experiment 1} \\
\hline $90.8 \mathrm{~kg}$ & 341.1 & 20.1 & 308.7 & 21.8 & 60.8 & 2.2 & 60.8 & 2.4 \\
\hline $225 \mathrm{~d}$ & 555.0 & 25.7 & 543.5 & 26.7 & 130.4 & 4.9 & 134.9 & 5.1 \\
\hline \multicolumn{9}{|c|}{ Experiment $2^{b}$} \\
\hline $120 \mathrm{~d}$ & 113.6 & 12.8 & 105.3 & 12.3 & 32.3 & 1.6 & 33.3 & 1.6 \\
\hline $141 \mathrm{~d}$ & 249.8 & 21.4 & 215.9 & 18.8 & 56.8 & 3.5 & 49.3 & 3.1 \\
\hline $162 \mathrm{~d}$ & 385.1 & 20.2 & 353.2 & 22.1 & 71.7 & 4.0 & 70.9 & 4.4 \\
\hline $183 \mathrm{~d}$ & 465.3 & 28.4 & 405.3 & 27.0 & 93.6 & 5.4 & 88.2 & 5.1 \\
\hline
\end{tabular}

${ }^{a}$ Adjusted for body weight.

${ }^{\mathrm{b}}$ Age linear and line $X$ age linear $(P<.05)$ effects for testes weight.

TABLE 5. LEAST-SQUARES MEANS FOR OVULATION RATE SELECT (OR), LEAN GROWTH SELECT (LG) AND WHITELINE (WL) FOR IN SITU TESTES MEASUREMENTS AND BODY WEIGHT IN EXPERIMENT 3

\begin{tabular}{|c|c|c|c|c|c|c|}
\hline \multirow[b]{2}{*}{ Line } & \multirow{2}{*}{$\begin{array}{l}\text { Measurement } \\
\text { age, d }\end{array}$} & \multicolumn{2}{|c|}{ Testes width $(\mathrm{cm})$} & \multicolumn{2}{|c|}{ Testis length $(\mathrm{cm})$} & \multirow{2}{*}{$\begin{array}{l}\text { Body } \\
\text { weight, } \mathrm{kg}\end{array}$} \\
\hline & & $\bar{x}$ & SE & $\overline{\mathbf{X}}$ & $\mathrm{SE}$ & \\
\hline \multicolumn{7}{|c|}{ Unadjusted for body weight ${ }^{a}$} \\
\hline OR & $\begin{array}{l}120 \\
140 \\
160\end{array}$ & $\begin{array}{r}8.33 \\
9.52 \\
11.76\end{array}$ & $\begin{array}{l}.24 \\
.27 \\
.25\end{array}$ & $\begin{array}{r}8.57 \\
10.07 \\
12.57\end{array}$ & $\begin{array}{l}.28 \\
.35 \\
.33\end{array}$ & $\begin{array}{l}52.7 \\
70.2 \\
96.8\end{array}$ \\
\hline LG & $\begin{array}{l}120 \\
140 \\
160\end{array}$ & $\begin{array}{r}7.88 \\
9.45 \\
10.87\end{array}$ & $\begin{array}{l}.22 \\
.13 \\
.23\end{array}$ & $\begin{array}{r}8.21 \\
9.93 \\
11.65\end{array}$ & $\begin{array}{l}.25 \\
.28 \\
.25\end{array}$ & $\begin{array}{l}62.6 \\
82.2 \\
99.9\end{array}$ \\
\hline WL & $\begin{array}{l}120 \\
140 \\
160\end{array}$ & $\begin{array}{r}8.69 \\
10.40 \\
11.47\end{array}$ & $\begin{array}{l}.15 \\
.13 \\
.13\end{array}$ & $\begin{array}{r}9.39 \\
11.28 \\
12.73\end{array}$ & $\begin{array}{l}.16 \\
.16 \\
.13\end{array}$ & $\begin{array}{l}53.9 \\
75.5 \\
74.5\end{array}$ \\
\hline \multicolumn{7}{|c|}{ Adjusted for body weight $t^{b}$} \\
\hline OR & $\begin{array}{l}120 \\
140 \\
160\end{array}$ & $\begin{array}{r}8.54 \\
9.98 \\
11.71\end{array}$ & $\begin{array}{l}.18 \\
.18 \\
.25\end{array}$ & $\begin{array}{r}8.74 \\
10.48 \\
12.54\end{array}$ & $\begin{array}{l}.22 \\
.24 \\
.28\end{array}$ & \\
\hline LG & $\begin{array}{l}120 \\
140 \\
160\end{array}$ & $\begin{array}{r}7.27 \\
9.01 \\
10.66\end{array}$ & $\begin{array}{l}.19 \\
.19 \\
.18\end{array}$ & $\begin{array}{r}7.69 \\
9.45 \\
11.49\end{array}$ & $\begin{array}{l}.24 \\
.25 \\
.21\end{array}$ & \\
\hline WL & $\begin{array}{l}120 \\
140 \\
160\end{array}$ & $\begin{array}{r}8.83 \\
10.42 \\
15.58\end{array}$ & $\begin{array}{l}.11 \\
.11 \\
.12\end{array}$ & $\begin{array}{r}9.50 \\
11.30 \\
12.81\end{array}$ & $\begin{array}{l}.13 \\
.14 \\
.14\end{array}$ & \\
\hline
\end{tabular}

\footnotetext{
${ }^{a}$ Effects $(P<.05)$ include line, age linear and line $X$ age quadratic interaction for testes width and testis length.

$\mathrm{b}_{\mathrm{Effects}}(\mathrm{P}<.05)$ include line, age linear and line $X$ age linear.
} 
paired with the sib mean. The total number of boar-relative records that were available from each experiment were: Exp. 1 (ORFS, 47-150; APFS, 44-97; NBORN, 102 pairs; NBORNI, 99 pairs); Exp. 2 (ORFS, 64-91; APFS, 78-156; DAMPUB, 86 pairs; NBORN, 89 pairs; NWEAN, 89 pairs); Exp. 3 (DAMPUB, 18 pairs; DAMOR, 35 pairs; NBORN, 48 pairs) and Exp. 4 (APFS, 71-157; NBORN, 71 pairs).

Correlations of testes measurements with backfat probe also were calculated. The boars in the first experiment were probed at $90.8 \mathrm{~kg}$ and probe backfat was measured at $140 \mathrm{~d}$ of age in Exp. 2, 3 and 4 and adjusted using body weight as a covariable.

\section{Results}

Exp. 1 and 2. The least-squares means for testes width and testis length are given in table 3. Results from Exp. 1 indicate that the in situ measurements increased most rapidly between the ages of 84 and $132 \mathrm{~d}$. The lines were not significantly different at any age; but in Exp. 2, the ovulation rate line tended to have larger means.

Least-squares means for excised testes weight are presented in table 4 . Line differences were not significant in Exp. 1, but the ovulation rate line had $10.5 \%$ heavier testes at 90.8 kg. In Exp. 2, testes weight increased linearly with age, but the rate of change was significantly different for the OR and CL lines. Testes weight for the OR line was from 9 to $15 \%$ heavier, depending on when measured.

Exp. 3 and 4. In situ testes measurements means for Exp. 3 and 4 are presented in tables 5 and 6 , respectively. Means were compared be-

TABLE 6. LEAST-SQUARES MEANS FOR OVULATION RATE SELECT (OR), LEAN GROWTH SELECT (LG) AND WHITELINE (WL) FOR IN SITU TESTES MEASUREMENTS AND BODY WEIGHT IN EXPERIMENT 4

\begin{tabular}{|c|c|c|c|c|c|c|}
\hline \multirow[b]{2}{*}{ Line } & \multirow{2}{*}{$\begin{array}{l}\text { Measurement } \\
\text { age, } d\end{array}$} & \multicolumn{2}{|c|}{ Testes width $(\mathrm{cm})$} & \multicolumn{2}{|c|}{ Testis length $(\mathrm{cm})$} & \multirow{2}{*}{$\begin{array}{l}\text { Body } \\
\text { weight, } \mathrm{kg}\end{array}$} \\
\hline & & $\overline{\mathrm{X}}$ & $\overline{\mathrm{SE}}$ & $\overline{\overline{\mathrm{x}}}$ & $\overline{\mathrm{SE}}$ & \\
\hline \multicolumn{7}{|c|}{ Unadjusted for body weight ${ }^{a}$} \\
\hline OR & $\begin{array}{l}100 \\
120 \\
140 \\
160\end{array}$ & $\begin{array}{r}6.38 \\
7.95 \\
10.06 \\
11.78\end{array}$ & $\begin{array}{l}.09 \\
.11 \\
.18 \\
.18\end{array}$ & $\begin{array}{r}7.30 \\
8.85 \\
10.54 \\
12.70\end{array}$ & $\begin{array}{l}.10 \\
.14 \\
.19 \\
.20\end{array}$ & $\begin{array}{l}37.4 \\
51.2 \\
67.3 \\
82.8\end{array}$ \\
\hline LG & $\begin{array}{l}100 \\
120 \\
140 \\
160\end{array}$ & $\begin{array}{r}6.10 \\
7.60 \\
8.87 \\
10.91\end{array}$ & $\begin{array}{l}.10 \\
.13 \\
.18 \\
.26\end{array}$ & $\begin{array}{r}6.85 \\
8.13 \\
9.49 \\
11.45\end{array}$ & $\begin{array}{l}.11 \\
.13 \\
.19 \\
.28\end{array}$ & $\begin{array}{l}37.9 \\
54.3 \\
74.6 \\
90.5\end{array}$ \\
\hline WL & $\begin{array}{l}100 \\
120 \\
140 \\
160\end{array}$ & $\begin{array}{r}6.43 \\
8.15 \\
9.98 \\
11.56\end{array}$ & $\begin{array}{l}.08 \\
.08 \\
.10 \\
.15\end{array}$ & $\begin{array}{r}7.10 \\
8.72 \\
10.51 \\
12.23\end{array}$ & $\begin{array}{l}.09 \\
.09 \\
.11 \\
.16\end{array}$ & $\begin{array}{l}33.2 \\
47.3 \\
65.3 \\
82.3\end{array}$ \\
\hline \multicolumn{7}{|c|}{ Adjusted for body weight ${ }^{a}$} \\
\hline OR & $\begin{array}{l}100 \\
120 \\
140 \\
160\end{array}$ & $\begin{array}{r}6.24 \\
7.90 \\
10.01 \\
11.82\end{array}$ & $\begin{array}{l}.08 \\
.11 \\
.16 \\
.25\end{array}$ & $\begin{array}{r}7.15 \\
8.79 \\
10.53 \\
12.67\end{array}$ & $\begin{array}{l}.09 \\
.12 \\
.16 \\
.28\end{array}$ & \\
\hline LG & $\begin{array}{l}100 \\
120 \\
140 \\
160\end{array}$ & $\begin{array}{r}5.92 \\
7.34 \\
8.63 \\
10.71\end{array}$ & $\begin{array}{l}.08 \\
.12 \\
.16 \\
.23\end{array}$ & $\begin{array}{r}6.67 \\
7.81 \\
9.28 \\
11.26\end{array}$ & $\begin{array}{l}.10 \\
.12 \\
.18 \\
.26\end{array}$ & \\
\hline WL & $\begin{array}{l}100 \\
120 \\
140 \\
160\end{array}$ & $\begin{array}{r}6.64 \\
8.34 \\
10.27 \\
11.83\end{array}$ & $\begin{array}{l}.07 \\
.10 \\
.13 \\
.20\end{array}$ & $\begin{array}{r}7.33 \\
8.96 \\
10.81 \\
12.58\end{array}$ & $\begin{array}{l}.08 \\
.10 \\
.14 \\
.23\end{array}$ & \\
\hline
\end{tabular}

\footnotetext{
length.

${ }^{\mathrm{a}}$ Effects $(\mathrm{P}<.05)$ include line, age linear, age quadratic and line $X$ age linear for both testes width and testis
} 
fore and after adjusting for body weight, which was quite different between lines. There were significant differences between the lines for rate and shape of the testicular growth curve. The LG line had heavier body weights at all ages than the OR and CL lines, but they had smaller testes measurements. In Exp. 3, boars of the LG line were 10 to $12 \mathrm{~kg}$ heavier than OR line boars, but they had smaller in situ testes measurements at 120 and $140 \mathrm{~d}$ of age. When the means were adjusted for body weight, the line differences became larger and the LG line had smaller in situ measurements at all ages in both experiments. Generally, the WL and OR lines had similar testes measurements.

The LG line had significantly lighter weight testes at 120 and $160 \mathrm{~d}$ of age than did the other lines (table 7). Averaged over experiments, testes and epididymides weights were similar for the OR and WL boars.

Histological data obtained from Exp. 4 are presented in table 8. At each age, LG boars had significantly fewer seminiferous tubules with active spermatogenesis and smaller tubule diameter. The differences were particularly large at $120 \mathrm{~d}$ of age. The percentage of the tubules with a lumen was considerably lower for the LG line at $120 \mathrm{~d}$ of age, but the lines were similar thereafter. The differences between the WL and OR lines were small.

Within Line Correlations. Correlations between excised testes weights and in situ testes measurements are shown in table 9. Correlations of in situ testes width and length with excised testes weight ranged from .76 to .93 . Correlations of epididymides weight and in situ measurements were lower than the correlations involving testes weight. The correlation between castration age and testes weight of the boars castrated at $90.8 \mathrm{~kg}$ was .42 , compared with correlations of .51 to .70 between body weight at castration and testes weight.

The correlations of testes weights and in situ measurements with seminiferous tubule diameter, percentage of tubules with active spermatogenesis and percentage with a lumen are presented in table 10 . Approximately $25 \%$ of the variation observed in the histological traits was explained by the measurements of testes size. Correlations of histological traits with body weight were between .29 and .36 . For boars of the same age, there is considerable variation in histological measurements that is independent of body weight.

Correlations of testes traits with reproductive

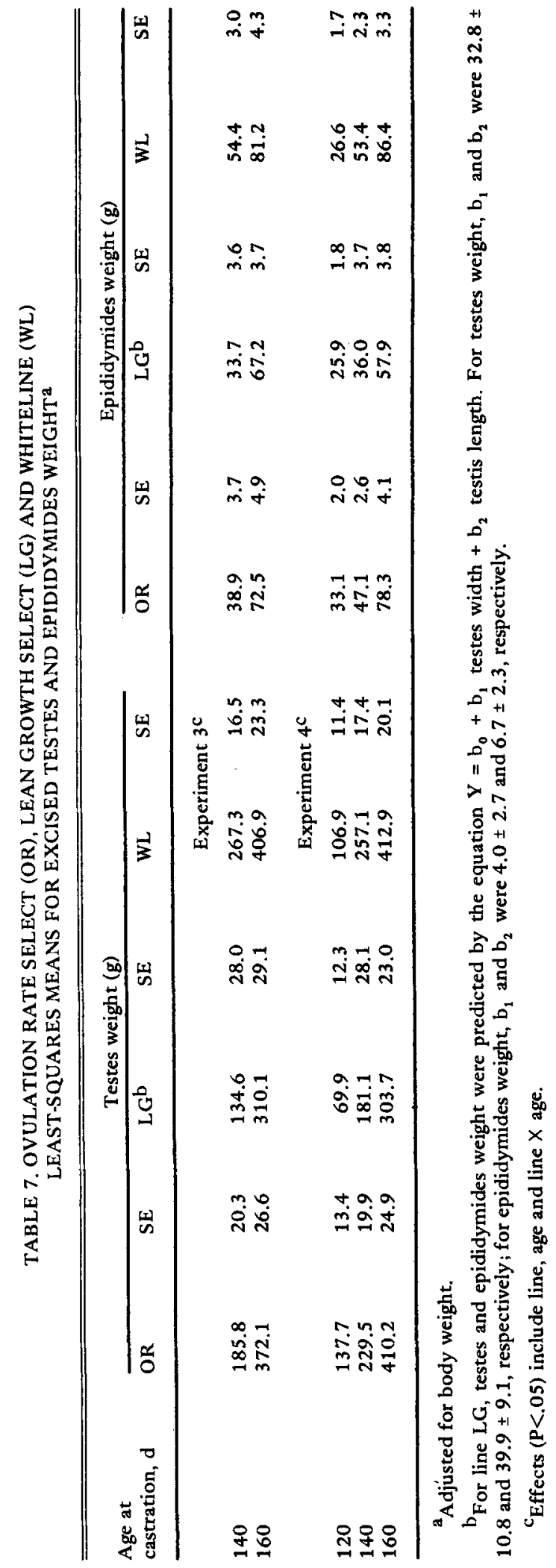


traits of female relatives are presented in table 11. Correlations of excised testes weights with ovulation rate of full sibs and the size of litter in which a boar was born are uniformily positive. The majority of the correlations between measures of testes size with age at puberty of full sibs and dam are negative. In Exp. 1, testes weight was positively correlated to backfat probe $(\mathrm{P}<.05)$; however, in the other experiments, these correlations were small and nonsignificant.

\section{Discussion}

In Exp. 2 and 4, testes weight more than tripled from 120 to $160 \mathrm{~d}$ of age. This rate of growth is similar to that found by McFee and Eblen (1967), but is less rapid than the 400 to $500 \%$ increase in testes weight found over the same age period by Hauser et al. (1952). Relatively, the rate of growth of excised testes weight was greater than for the in situ measurements. This was most likely due to the fact that weight estimates volume (length times width times depth) while width and length are linear measurements.

The data suggest that selection for ovulation rate has resulted in a 10 to $12 \%$ increase in testes weights at 140 to $160 \mathrm{~d}$ of age. Land (1973), Islam et al. (1976) and Joakimsen and Baker (1977) also have found correlated responses between testes size and ovulation rate in mice.
Boars selected for rate of lean growth were from 14 to $20 \mathrm{~d}$ older than the OR and WL line boars upon reaching the same degree of testicular development. Selection for ovulation rate has increased testes size over the CL line, but the majority of the differences between the LG and OR lines appears to have been caused by a negative genetic relationship between the index and testes weight. Perhaps the effect of selection for lean growth has been to delay maturity, both compositionally and sexually. Allrich et al. (1981) found a decrease in testes weights in a line of rats selected for lean efficiency; a line in which body composition and daily gain changed in the same direction as has been found for the LG line (Wang et al., 1980; Cleveland et al., 1982).

Selection did not have a detrimental effect on female reproductive performance of the LG line. Williams (1981) evaluated the LG line via a diallel mating design and failed to find any significant line of sire effects for age at first estrus, ovulation rate or number of normal embryos. Cleveland (1981) did not detect any significant correlated response in the LG line for number born or number weaned.

Some care must be exercised when interpreting the correlations between growth rate and testis size. Average daily gain is a function of both weight and age. The relationship between growth rate and testes weight depends upon which variable, age or weight, is held constant.

TABLE 8. LEAST-SQUARES MEANS FOR HISTOLOGICAL TRAITS FOR OVULATION RATE SELECT (OR), LEAN GROWTH (LG) AND WHITELINE (WL) BOARS (EXP. 4)

\begin{tabular}{|c|c|c|c|c|c|c|c|}
\hline \multirow[b]{2}{*}{ Trait $^{\mathbf{a}}$} & \multirow[b]{2}{*}{ Age, d } & \multicolumn{2}{|c|}{ WL } & \multicolumn{2}{|c|}{ OR } & \multicolumn{2}{|c|}{ LG } \\
\hline & & $\bar{X}$ & SE & $\overline{\mathbf{x}}$ & $\mathrm{SE}$ & $\overline{\mathrm{X}}$ & SE \\
\hline SPERM, \%b & $\begin{array}{l}120 \\
140 \\
160\end{array}$ & $\begin{array}{l}21.2 \\
74.9 \\
91.4\end{array}$ & $\begin{array}{l}8.8 \\
7.3 \\
7.1\end{array}$ & $\begin{array}{l}44.1 \\
79.4 \\
90.5\end{array}$ & $\begin{array}{l}9.3 \\
8.8 \\
7.3\end{array}$ & $\begin{array}{r}.4 \\
48.0 \\
77.4\end{array}$ & $\begin{array}{r}8.8 \\
11.8 \\
8.4\end{array}$ \\
\hline LUMEN, $\%^{\mathrm{c}}$ & $\begin{array}{l}120 \\
140 \\
160\end{array}$ & $\begin{array}{l}43.9 \\
82.1 \\
90.6\end{array}$ & $\begin{array}{l}7.0 \\
5.9 \\
5.6\end{array}$ & $\begin{array}{l}66.5 \\
85.3 \\
93.1\end{array}$ & $\begin{array}{l}7.5 \\
8.8 \\
7.5\end{array}$ & $\begin{array}{r}9.4 \\
82.2 \\
83.7\end{array}$ & $\begin{array}{l}7.0 \\
9.4 \\
6.7\end{array}$ \\
\hline TUBDIA,$\mu \mathrm{m}^{\mathrm{b}}$ & $\begin{array}{l}120 \\
140 \\
160\end{array}$ & $\begin{array}{r}90.2 \\
137.2 \\
157.4\end{array}$ & $\begin{array}{l}8.4 \\
7.3 \\
6.7\end{array}$ & $\begin{array}{l}113.0 \\
134.1 \\
160.2\end{array}$ & $\begin{array}{l}8.8 \\
8.4 \\
8.9\end{array}$ & $\begin{array}{r}68.3 \\
116.0 \\
136.1\end{array}$ & $\begin{array}{r}8.4 \\
11.2 \\
7.9\end{array}$ \\
\hline
\end{tabular}

\footnotetext{
${ }^{a}$ SPERM = percentage of seminiferous tubules with active spermatogenesis; LUMEN = percentage of seminiferous tubules with a lumen; TUBDIA = seminiferous tubule diameter.

${ }^{b}$ Effects $(P<.05)$ include line and age.

${ }^{\mathrm{C}}$ Effects $(\mathrm{P}<.05)$ include line, age and line $X$ age.
} 
TABLE 9. CORRELATIONS OF TESTES WIDTH (TWH), TESTIS LENGTH (TL) AND AGE OR BODY WEIGHT AT THE TIME OF CASTRATION WITH TESTES (TW), EPIDIDYMIDES (EW) AND TOTAL TESTES WEIGHTS (TTW) ${ }^{a}$

\begin{tabular}{lllll}
\hline \hline Trait & TW & EW & TTW \\
\hline
\end{tabular}

Exp. 1: 52 pairs of observations

Boars castrated at $90.8 \mathrm{~kg}$

$\begin{array}{llll}\text { TL } & .81 & .61 & .81 \\ \text { TWH } & .81 & .61 & .81 \\ \text { Castration age } & .42 & .41 & .43\end{array}$

Boars castrated at $225 \mathrm{~d}$ of age: 49 pairs of observations

$\begin{array}{llll}\text { TL } & .77 & .71 & .80 \\ \text { TWH } & .83 & .72 & .84 \\ \text { Castration wt } & .55 & .34 & .52\end{array}$

Exp. 2: 90 pairs of observations

$\begin{array}{llll}\text { TL } & .76 & .60 & .77 \\ \text { TWH } & .78 & .56 & .79 \\ \text { Castration wt } & .64 & .52 & .63\end{array}$

Exp. 3: 48 pairs of observations

$\begin{array}{llll}\text { TL } & .82 & .68 & .81 \\ \text { TWH } & .80 & .60 & .79 \\ \text { Castration wt } & .51 & .51 & .52\end{array}$

Exp. 4: 90 pairs of observations

\begin{tabular}{llll} 
TL & .93 & .83 & .93 \\
TWH & .92 & .82 & .92 \\
Castration wt & .70 & .74 & .71 \\
\hline
\end{tabular}

\footnotetext{
${ }^{a}$ Pooled within line correlations for Exp. 1. Remaining correlations are pooled within line and castration age. All correlations are significant $(\mathrm{P}<.01)$.
}

For boars castrated at a standard weight $(90.8$ $\mathrm{kg}$ ), there was a positive correlation between age and testes weight. As the older boars would be the slower growing ones, this implies that the slower growing boars have heavier testes at a standard body weight. Presumably at a standard weight, the older boars are physiologically more mature. For boars castrated at a standard age, the correlations between body weight at castration and testes weight are also positive (.51 to .70). As heavy boars at a standard age would be the faster growing ones, this implies that faster growing boars have heavier testes at a standard age. This is likely caused by the part-whole relationship of testes weight to body weight.

Correlations of testes weights and in situ measurements at the time of castration ranged from .76 to .93 , and suggest that in situ measurements can be used to predict excised testes weights. Correlations of .55 and .56 of testes width and testes length with the percentage of seminiferous tubules with active spermatogenesis suggest that young boars with larger testes measurements are expected to be more advanced with regard to sexual maturation.

Testicular traits appear to have desirable correlations with reproductive performance of female relatives. Correlations involving the mean performance of full sisters (ORFS and APFS) can be evaluated by the formula $r_{F S}=1 / 2$ $h_{1} h_{2} r_{G}$ na, where $n$ is the harmonic mean of the number of full sisters/boar, $a$ is the standard partial regression of the phenotypic mean of a family on an individual observation, $h_{1}$ is the square root of heritability for the female trait and $h_{2}$ the square root of heritability for the testes measurement. Heritability estimates of .45 and .40 for ovulation rate and age at puberty, respectively, have been observed (Young et al., 1978; Cunningham et al., 1979). If the heritability of testes weight is between .3 and .6 , the estimated genetic correlation, $\mathrm{r}_{\mathrm{G}}$, between ovulation rate and testes weight ranges from .56 to .39 and .65 to .46 for Exp. 1 and 2, respectively. The correlations between testes measurements and female traits were not significant and the standard errors of estimates

\section{TABLE 10. CORRELATIONS OF MEASURES OF TESTES SIZE AND CASTRATION WEIGHT WITH HISTOLOGICAL TRAITS ${ }^{a}$}

\begin{tabular}{|c|c|c|c|}
\hline \multirow{2}{*}{$\begin{array}{l}\text { Testes } \\
\text { measurement }\end{array}$} & \multicolumn{3}{|c|}{ Histological traits $c$} \\
\hline & SPERM & TUBDIA & LUMPER \\
\hline TL & .55 & .60 & .52 \\
\hline TWH & .56 & .61 & .54 \\
\hline TW & .57 & .59 & .50 \\
\hline $\mathrm{EW}$ & .38 & .47 & .31 \\
\hline TTW & .55 & .58 & .48 \\
\hline Castration wt & .29 & .36 & .30 \\
\hline
\end{tabular}

${ }^{a}$ Correlations are pooled within line and castration age $(85$ boars). All correlations are significant $(P<.01)$.

$\mathrm{b}_{\mathrm{TL}}=$ in situ testes length, $\mathrm{TWH}=$ in situ testes width, $\mathrm{TW}=$ testes weight, $\mathrm{EW}=$ epididymides weight and TTW = testes + epididymides weight.

$c_{\text {TUBDIA, SPERM and LUMPER }}=$ seminiferous tubule diameter, percentage of tubules with active spermatogenesis and percentage of tubules with a lumen, respectively. 


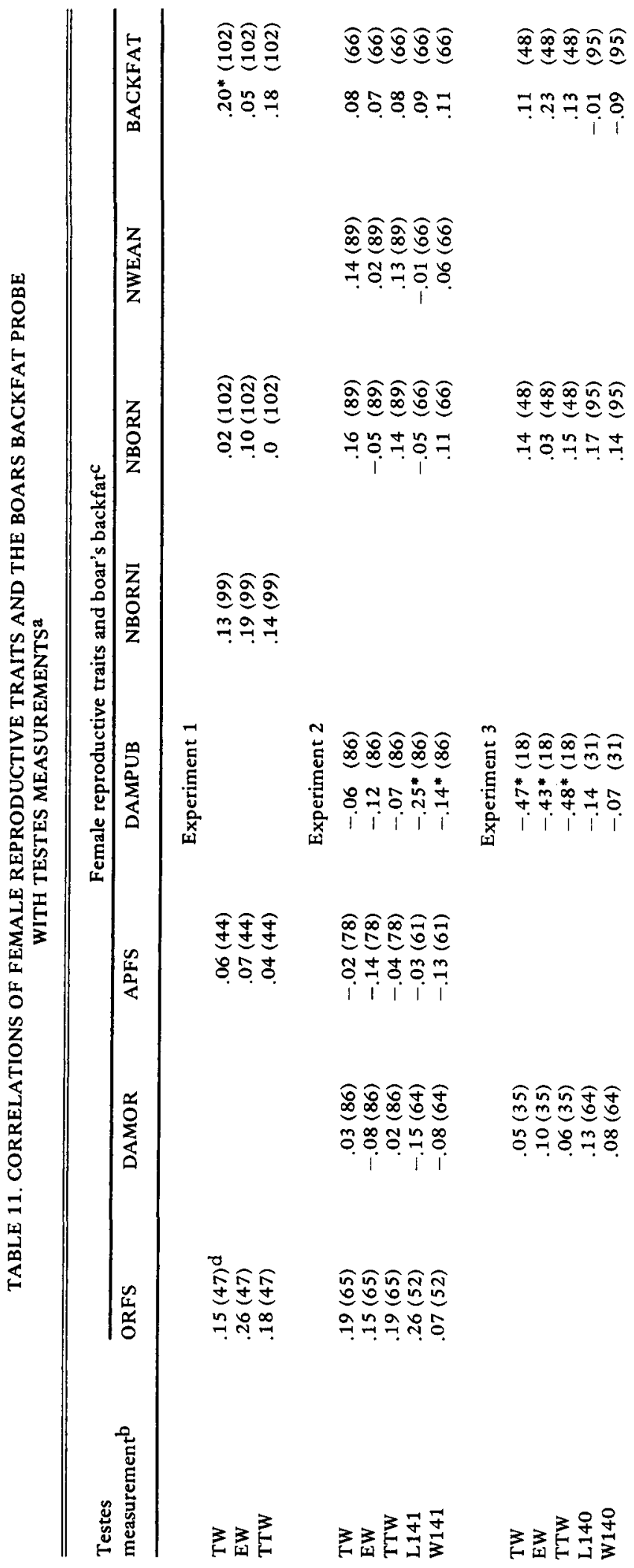




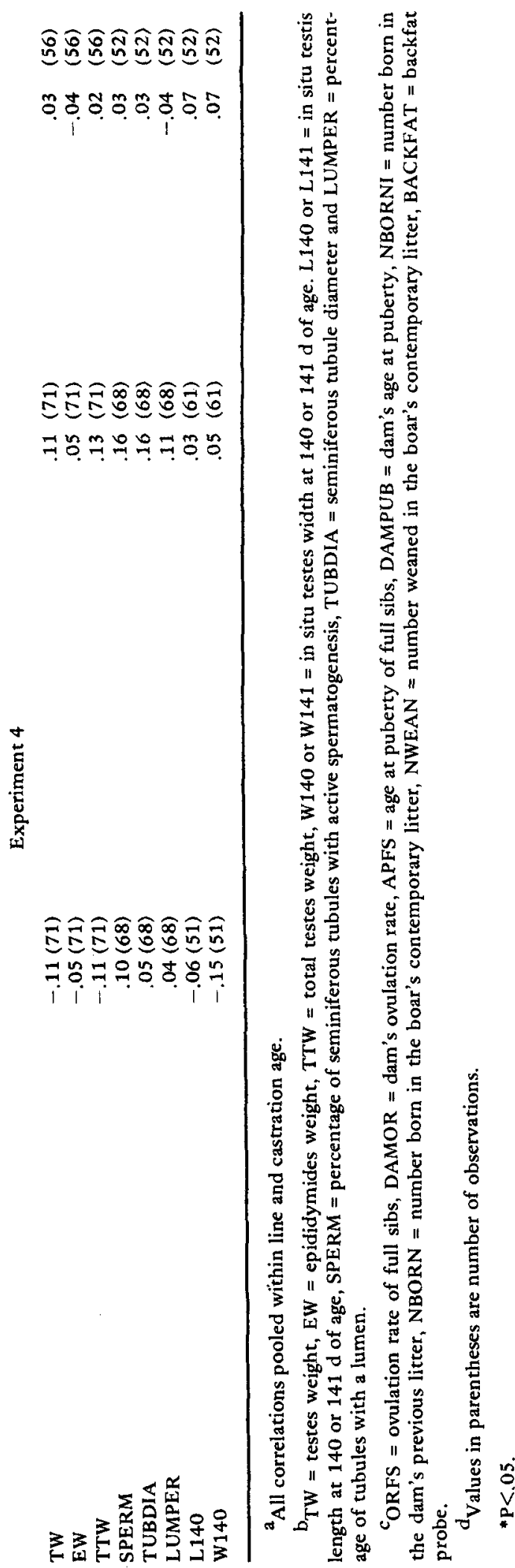

of $r_{G}$ would be large. Correlations of testes weight with ovulation rate of dams were smaller than those with ovulation rate of sibs and equal

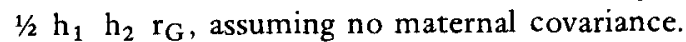
The correlations between testes weights and size of dam's previous litter (NBORNI) are influenced less by maternal effects than correlations of testes weights and size of litter in which a boar is born. These and the correlations of measurements of testes size with size of litter a boar is born in, áge at puberty of full sibs, and dam's age at puberty suggest that testes size may be related to female reproductive performance.

\section{Literature Cited}

Allrich, R. D., C. T. Wang, G. E. Dickerson and D. R. Zimmerman. 1981. Selection for increased rate or efficiency of lean growth in rats: Correlated responses in reproductive performance. J. Anim. Sci. 53:1458.

Andresen, 0.1976 . Concentrations of fat and plasma $5 \alpha$-androstenone and plasma testosterone in boars selected for rate of body weight gain and thickness of backfat during growth, sexual maturation and after mating. J. Reprod. Fertil. $48: 51$

Carr, R. W. and R. B. Land. 1973. Plasma luteinizing hormone levels and testis diameter of ram lambs of different breeds. J. Reprod. Fertil. 42:325.

Cleveland, E. R. 1981. The effect of lean growth selection and feed intake on composition and energy utilization in swine and correlated responses in carcass and reproductive traits from lean growth selection in swine. Ph.D. Dissertation, Univ. of Nebraska, Lincoln.

Cleveland, E. R., P. J. Cunningham and E. R. Peo, Jr. 1982. Selection for lean growth in swine. J. Anim. Sci. 54:719

Cunningham, P. J., M. E. England, L. D. Young and D. R. Zimmerman. 1979. Selection for ovulation rate in swine: Correlated response in litter size and weight. J. Anim. Sci. 48:509.

England, M. E., P. J. Cunningham, R. W. Mandigo and D. R. Zimmerman. 1977. Selection for ovulation rate in swine: Correlated response in carcass traits. J. Anim. Sci, 45:983.

Gray, R. C., B. N. Day, J. R. Lasley and L. F. Bribble. 1971. Testosterone levels of boars at various ages. J. Anim. Sci. $33: 124$.

Hauser, E. R., G. E. Dickerson and D. T. Mayer. 1952. Reproductive development and performances of inbred and crossbred boars. Missouri Agr. Res. Bull. 503.

Islam, A.B.M., W. G. Hill and R. B. Land. 1976. Ovulation rate of lines of mice selected for testes weight. Genet, Res. 27:23.

Joakimsen, O. S. and R. L. Baker. 1977. Selection for litter size in mice. Acta Agr. Scand. 27:301.

Land, R. B. 1973. The expression of female sexlimited characters in the male. Nature 241:208. 
McFee, A. F. and J. R. Eblen. 1967. Testicular development in miniature swine. J. Anim. Sci. 26:772.

Neely, J. D., B. H. Johnson and O. W. Robison. 1979. Heterosis estimates of measures of reproductive traits in crossbred boars. Proc. of Southern Agr. Workers. New Orleans, LA. 10.

Newton, J. R., r. J. Cunningham and D. R. Zimmerman. 1977. Selection for ovulation rate in swine: Correlated response in age and weight at puberty, daily gain and probe backfat. J. Anim. Sci. 44:30.

SAS. 1979. SAS User's Guide. Statistical Analysis System Institute, Inc., Cary, NC.

Wang, C., G. E. Dickerson, S. E. Hadden and J. A. DeShazer. 1980. Feed utilization of rats selected for rate and for efficiency of lean growth. Zeits.
F. Tierz. U. Zuchtungsb. 97:217.

Williams, S. R. 1981. Selection for lean growth in swine: Effects on growth, carcass and reproductive performance. M.S. Thesis. Univ. of Nebraska, Lincoln.

Wilson, E. R., R. K. Johnson and R. P. Wettemann. 1977. Reproductive and testicular characteristics of purebred and crossbred boars. J. Anim. Sci. 44:939.

Young, L. D., R. A. Pumfrey, P. J. Cunningham and D. R. Zimmerman. 1978. Heritabilities and genetic and phenotypic correlations for prebreeding traits, reproductive traits and principal components. J. Anim. Sci. 46:937.

Zimmerman, D. R, and P. J. Cunningham. 1975. Selection for ovulation response. J. Anim. Sci. $40: 61$. 